\title{
Work organization and the health of bank employees
}

\author{
Juliana Lemos Silva ${ }^{1}$ \\ Vera Lucia Navarro ${ }^{2}$
}

\begin{abstract}
The Brazilian banking sector has undergone an intense restructuring process and taken a leading position in the incorporation of new technologies and organizational innovations. Computerization in the industry, in association with forms of work organization, has resulted in changes that reflect on the workers' health. Based on the theoretical and methodological frameworks of historical and dialectical materialism, this qualitative study investigates the work conditions of bank employees in order to identify the extent to which changes in work organization interfere with these workers' health. Data were collected through interviews held with 11 bank employees. In addition to physical sickening due to occupational diseases directly related to work intensification, the results also show an increased incidence of mental suffering and a feeling of loss of professional identity. Work-related frustration, instability and concerns related to psychological pressure resulting from the need to achieve goals predominated in the reports.
\end{abstract}

Descriptors: Work; Working Conditions; Occupational Health; Occupational Diseases.

\footnotetext{
1 MSc, Professor, Universidade Federal do Triângulo Mineiro, Brazil.

2 PhD, Professor, Faculdade de Filosofia, Ciências e Letras de Ribeirão Preto, Universidade de São Paulo, Brazil.
} 


\section{Organização do trabalho e saúde de trabalhadores bancários}

O setor bancário brasileiro passou por intenso processo de reestruturação e ocupou posição de liderança na incorporação de novas tecnologias e inovações organizacionais. A informatização do setor, aliada às novas formas de organizar o trabalho, resultou em mudanças que refletiram na saúde dos trabalhadores. Fundamentado no referencial teórico metodológico do materialismo histórico-dialético, este estudo, de caráter qualitativo, teve por objetivo investigar as condições de trabalho de bancários, para identificar em que medida as mudanças na organização do trabalho interferiram na saúde daqueles trabalhadores. Os dados foram coletados através de entrevistas com onze bancários. Os resultados revelaram, além de adoecimentos de ordem física por doenças ocupacionais, diretamente relacionadas à intensificação do trabalho, o aumento da incidência de sofrimento mental e sentimento de perda de identidade profissional. Predominaram, nos depoimentos, sentimentos de frustração e insegurança em relação ao trabalho e preocupação com a pressão psicológica, derivada da necessidade de cumprimento de metas.

Descritores: Trabalho; Condições de Trabalho; Saúde do Trabalhador; Doenças Profissionais.

\section{Organización del trabajo y salud de empleados del banco}

La Banca Brasileña pasó por un intenso proceso de reestructuración y ha ocupado posiciones de liderazgo en la incorporación de nuevas tecnologías e innovaciones organizacionales. La informatización de la industria, junto con nuevas maneras de organización del trabajo, dio lugar a cambios que reflejaron en la salud de los trabajadores. Con base en el marco teórico y metodológico del materialismo histórico y dialéctico, este estudio cualitativo tuvo como objetivo investigar las condiciones laborales de los empleados del banco para identificar el grado en que los cambios en la organización del trabajo influyeron en la salud de los trabajadores. Los datos fueron recolectados a través de entrevistas con once empleados del banco. Los resultados mostraron, además de las enfermedades físicas profesionales directamente relacionadas con la intensificación del trabajo, aumento de la incidencia de sufrimiento mental y la sensación de pérdida de identidad profesional. Predominaron en las entrevistas sentimientos de frustración e inseguridad sobre el trabajo y la preocupación por la presión psicológica de la necesidad de logro de los objetivos.

Descriptores: Trabajo; Condiciones de Trabajo; Salud Laboral; Enfermedades Profesionales.

\section{Introduction}

Diverse sectors in the Brazilian economy underwent organizational rearrangements in terms of productive restructuring, which mainly intensified in the 1990s. The financial sector was a pioneer in incorporating new technologies and organizational innovations and experienced intense structural adjustment from the globalization of the financial system, already underway in the 1980 s and which intensified in the $1990 \mathrm{~s}^{(1-2)}$.
Such a process takes place in a context of increased competition between Brazilian and international banks, institutional changes, implementation of economic plans beginning in the 1980s and 1990s, specifically the Cruzado and Real plans, and reduced inflationary rates ${ }^{(3)}$. The basis of new demands and qualifications required in the sector is grounded on three characteristic social phenomena: unemployment, poor work contracts, and 
increased workload ${ }^{(3)}$. The substantial changes that took place with the productive restructuring were designed to implement strategies such as charging clients for a greater diversity of services and products, escalating outsourcing, making labor more flexible, redefining tasks and traditional banking activities, and transferring many of the services to the clients themselves (i.e. through ATMs and online banking)(1).

Bank employees had their "constitutive features" redefined and became "bank-sellers", qualified to fully assist their clients in an individualized manner in order to achieve goals imposed on them, such as the sale of bonds, insurance, investments, and other bank products and services(4). In this new management model, bank employees gained more functionality, "qualifications" and versatility to become "expert sellers" (5).

These changes, which took place in the process of productive restructuring, not only affected the way of being of bank employees, they also affected their health. As technology applied in banking became increasingly more sophisticated, the frequency of occupational diseases also increased, as observed in the studies reported, some of which directly focused on these issues. Some authors assert that both the process of automation and redefinition of the profile of the work performed by bank employees are accountable for the process in which these workers become sick. Complaints concerning tension, stress, and pressure experienced within banks increase in response to changes ${ }^{(6)}$. Despite a significant bibliography on the subject, and because it refers to a collective health problem, studies like this are justified because they can help to clarify the problem and support surveillance agencies responsible for monitoring workplaces and public policies addressing the subject.

\section{Objectives}

Based on these changes, this study investigated work conditions in a private bank in Uberaba, MG, Brazil to identify the extent to which changes in work organization have interfered in the health of bank employees.

\section{Method}

This is a qualitative study based on the theoretical and methodological framework of historical dialectical materialism. The bibliography that supported data analysis gave priority to texts focused on the changes that occurred in the universe of work, highlighting issues related to productive restructuring, especially that which occurred in the Brazilian banking sector, and the impact of these transformations on the working conditions and health of these workers, seeking to understand the object of study in its entirety. Data were collected between 2008 and 2009 through semi-structured interviews conducted with 11 workers from various hierarchical levels of a private bank in Uberaba, MG, Brazil who freely consented to participate in the study. Inclusion criteria were: being an employee of the bank at the time of data collection, and at least half of the interviewees should have worked more than ten years in the studied bank. Interviews were recorded and held at the participants' households. The number of participants depended on how the study progressed, including quality of data collected through the interviews, capacity to understand breadth, depth, and saturation of information or recurrent information.

In addition to the interviews held with the bank employees, information from other sources was also included: consultation of historical documents and secondary data from the labor union and the city's public archives. Additional data that helped to understand the study's object and reconstitute the work process were obtained through interviews with a psychologist, with the president of the Bank Employees Union in Uberaba and Region and with two retired bank employees. The material obtained through testimonies was submitted to thematic analysis. The selected testimonies were divided into themes related to the study's objects and enabled the reconstitution of the work process, and highlighted changes and their impact on the health of workers. As the work process was reconstituted, based on information collected in the testimonies and bibliography consulted, the results and discussion were presented concomitantly, intertwining theory and empiricism in the same section, highlighting the relationships between labor and the health problems reported by the workers. This study complied with ethical requirements of Resolution 196/96, National Council of Health, for studies involving human subjects and was approved by the Ethics Research Committee at Hospital das Clinicas, Medical School, University of São Paulo at Ribeirão Preto (Process HCRP no 11021/2007).

\section{Results and discussion}

\section{Bank work in the context of productive restructuring}

In Brazil, the history of bank work can be divided into three stages. The first, up through the 1960s, was when workers had control over their work. The second stage, up to the $1980 \mathrm{~s}$, is characterized by the predominance 
of Taylorism-Fordism, based on pre-defined routines and computer programs, which disqualified bank employees as the knowledge demanded in the previous phase was discarded. The 1980s were marked by a diffusion of computers in the bank work environment. Part of bank employees' activities was transferred to clients- the supply of self-service equipment is emblematic- and a great part of information became available online ${ }^{(7)}$. The last stage, from the 1990s on, is characterized by increased automation and, consequently, a sharp reduction and elimination of job positions ${ }^{(7)}$. At this point, work intensified, workloads were no longer respected, and wage degradation worsened working conditions. Traditional bank work was limited to activities performed in banking agencies. Bank operations basically came to comprise accounting, receiving deposits, collecting taxes and payments, discounting bonds, and performing loans and financial investments ${ }^{(8)}$. One of the interviewees made the following comment: [...] we used the telex to report the cashing of checks. We really were bank employees at the beginning. It was very different from what we do nowadays. At the beginning, I was a bank employee. We added checks, calculated and checked numbers. Not anymore, now we actually work with sales. (Interviewee 6).

This "old way of working"(9), essentially bureaucratic and based on technical knowledge, with many promises of desired promotions, the guarantee of good salaries and a career for life, contrasts with the "new way of working"(9), implemented at a time characterized by automation where work is reduced to purely technical functions. It is important to note that working in a bank had some social status because its environment was considered pleasant, modern, clean, and did not require bodily strength compared to industrial activities or those in the agricultural sector, for instance.

Expropriation of knowledge was one of the main consequences of the organizational changes that occurred in the banking world, according to both the reports in the field and the testimonies of the interviewees. Banking work has, since the rise to dominance of the principles of Taylorism, undergone an intense process of "disenchantment of the old métier"(10).

Following a worldwide rationale, restructuring strategies were adopted by banks, which delegated financial consulting and the commercialization of new products and services to the new bank employees ${ }^{(6)}$. Workers from the commercial sectors became valued and were recognized as qualified while those in the administrative sectors were recognized as semi-qualified employees $^{(11)}$. The following report is obtained from one of the interviewees concerning this disqualification of work: I sell money, sell money. Bank employees are currently money sellers. These workers no longer only deal with money... I sell money, products and services. Bank employees are done. I don't think we should be called bank employees but bank commercial representatives. (Interviewee 6).

The new profile consists of workers who are able to constantly adapt to change ${ }^{(12)}$. The current way of working requires a bank employee with a more generalist conception having the skills to deal with unexpected, subjective and diversified situations, apt to skillfully and rapidly and physically handle machines, and achieve production goals established by upper level managers: $I$ guess that pressure today is much greater; banking is currently commerce. So a manager gets disoriented because he has to meet goals every day, every month... You sell 20 products this month. Next month the guy comes and wants another 40 and it's really small here for so much competition, there are a lot of banks, demand increases and increases, and there's not so many people to buy the same products. The manager gets trapped. And in these cases, sometimes, they are fired because they are not producing enough...(Interviewee 10)

Along with the process in which the profession's social status disintegrates-not only does the profession disintegrate, but the very knowledge acquired over years-bank employees have also borne the burden of devaluation(13). Deprivation of meaning stamped into organizational standards reflects on workers in terms of an inability to achieve self-realization and recognition for performing meaningless tasks without choice ${ }^{(13)}$.

An attitude of disregard in the face of the bank employees' problems and suffering is frequently attributed to the bureaucratic behavior adopted by their superiors. Such a behavior is adopted given a fear concerning the image of their banking agency in relation to the other agencies in the same bank, which impedes listening to bank employees and hinders their complaints becoming public. The figure of the manager when $\mathrm{s} /$ he transfers obligations and goals is presented as a position of leadership. When, however, workers need to report to someone, the manager becomes just another employee, avoiding responsibility and attributing it to the institution. Additionally, the feeling of being disposable is striking, as the following report shows: ... because there's no one to defend you, you're on your own [...] I sent a [sick note] to the administrative department on a Monday. He only called me to communicate he considered it an absence because he didn't know what had happened to me. I got sick and went to the hospital but he didn't know what had happened. He didn't even become concerned and call me. I'd 
already got sick in the bank, fainted twice, three times including the last one, and my manager has never even called me... My right side became compromised, all paralyzed. You feel that when you've achieved the goals you're excellent. The day you don't achieve the same goals you've achieve before, forget it. Now whenever they have something to communicate to me, they send a telegram [...] To this day, nobody [from the bank] has ever called me... (Interviewee 9).

Another aspect concerning changes suffered in bank work and practiced by the studied institution was the growing number of clerks, young individuals at the beginning of their careers, hired by the bank. It shows the intention to recruit people without previous experience who submit themselves to the bank's power without questioning. According to a study of organizational culture(14), organizations have defined criteria concerning recruitment and selection, preferring to hire young individuals without previous experience in another financial institution. The workforce is seen as "raw material to be molded and shaped according to the organizational cultural values, beliefs, and behavior"(14). The institution benefits from scarce possibilities of employment in the city and manages to 'herd' young individuals to their agencies, offering them 'higher' salaries (compared to other activities in the city), sixhour workloads, qualifications and other illusory perks, such as participation in the company's profits. Clerks are generally young students with a disposition to incorporate the educational process directed to their complete socialization within the company. This "closed career"(14) $^{\prime \prime}$ system teaches incoming young employees the way of thinking and acting according to the institution's values $^{(15)}$, called "exemplary behavior"(15), ensuring the institution a dedicated, submissive and disciplined employee, as reported by one of the interviewees: Look, this girl and I, she started in January and I started in April; she already got a promotion four months ago, so mine will be somewhere around the same time she got hers, less than a year to get promoted. (Interviewee 4)

Such a report reveals another trend in the studied institution: little time is required for a clerk to be promoted. There are, in addition to the job postings in the studied bank's functional structure, also subdivisions recognized by letters such as bank teller A, B, and C, for instance. Going from one letter to another is another way to motivate employees, rather than necessarily valuing them, increasing salaries, giving more autonomy in the decision-making process or advancing them hierarchically. The younger employees have much less experience and practice than experienced workers in this rapid hierarchical ascension: When I entered the bank, for someone to be promoted to the position I am now, I worked 13 years as a bank teller. Nowadays, a person does not work more than two years as a bank teller and already gets a promotion. It was all very different when I started. For you to get a account relations manager position it would be like what? Twelve, ten years. Today, an employee with two or three years is already an account manager (Interviewee 9)

Contrary to the logic of making a career within organizations, there is a tendency, already observed(10) beginning in the 1970 s and confirmed ${ }^{(10)}$ in the following decade, that new bank employees do not consider the bank to be a "complete institution, to which one adheres for their entire life" ${ }^{(10)}$. Being a bank worker is seen as a provisory and temporary situation, a bridge to put into practice other personal projects such as completing an undergraduate program ${ }^{(10)}$. In the view of some scholars(13), these new managers, without any expectation to remain in the bank, also contribute to "degrade the profession's status" (13). In this same line of reasoning, hiring this "new" profile of workers was considered a "break in bank tradition"(10). Organizations no longer recognize in their traditional staff the qualities required by the new demands in the market and seek external sources of raw material. The young bank employees occupying privileged positions have "great potential and a college degree but do not have knowledge concerning the bank(10)": This is something I consider to be wrong: you're no longer useful after you turn 40 . And I don't think this is true, I guess you become even better with maturity. I see my 20 year-old colleagues... I mean, their age is the same quantity of years $I$ have of experience, and you see they are distracted, have no maturity. [...] And every bank wants this, a person entering college; they don't even want those about to graduate. (Interviewee 10)

Reports revealed that bank employees are consumed by work and make clear that "they are not required in the company's future, which puts them in a situation of being disposable, helpless in relation to their own future"(9). The context of banks based on "technological development at the service of capital transforms a great part of the bank workforce into something disposable, unnecessary to the devastating process of capital self-valorization"(16). Hence, within this exploratory rationale, when the "useful body" becomes sick as a consequence of the work itself, it becomes incompatible with the world of work, and the body that once served, is now despised.

[...] I have no words. It destroys us from inside. You work honestly, treat your clients with love... and then at the end of the day, you feel like garbage (Interviewee 9). 
The lack of interest in making a career in the studied institution is aggravated by problems faced in the workers' routines. The increased demands for qualifications, pressure to achieve goals, inconstancies that generate insecurity, work overload, the destitution of "know how" and degradation of the profession's status are elements responsible for these workers' suffering.

\section{Work changes and affects on health}

The growing automation and computerization process within bank work implied changes in organization, work conditions and relationships. The adoption of new technologies and new ways to manage the workforce resulted in, among other things, intensification of the work pace, task overload, fewer working positions, increased pressure and control over workers, reflecting on their health condition.

Both the automation process and redefinition of the bank work profile are responsible for the process in which workers become sick(6). This opinion is shared by researchers who describe the situation of bank employees who are "face to face with the new work organization" (17). Being forced to long work journeys, struggling to achieve abusive goals, pressure to produce and excessive control over work time combine to produce stress and mental suffering(17). This is what one of the interviewees also reported: [...] everybody who works there is a bit crazy, everybody is a little stressed. It's the stress, the demand that generates stress, the hectic life that generates stress, everything generates stress, I guess the worst thing about these days is stress. (Interviewee 6).

The existence of mental disorders caused by working in a bank is aggravated by a fear accruing from the unpredictability of some work situations and job instability. Fear of unemployment is always a reality in banking organizations, especially due to the fact that workers are not able to maintain the performance demanded by new managers, which results in instantaneous layoffs and an uncertainty that rights are guaranteed ${ }^{(18)}$.

I guess that the main problem today is the fear bank employees experience; perhaps it is this instant layoff, uncertainty of the future, uncertainty whether you'll have a place to work [...] the greatest fear perhaps is uncertainty, you're working today and tomorrow you may not be [...] (Interviewee 3).

"What a paradox!" they exclaimed(19) when reporting the growing number of diseases in work environments considered to be clean. Bank employees are subject to invisible risks that can harm their physical and mental integrity. The pressure, accelerated pace of work, moral harassment and abusive goals account for the high level of absenteeism due to health conditions and an incapacity to work. These authors assert that "we are no longer faced with occupational diseases linked to traditional labor, we are rather faced with new forms of suffering, against which known responses are not efficient" (19). The occurrence of Work-Related Musculoskeletal Disorders (WRMD) and Repetitive Strain Injury (RSI) among employees of the studied institution was highlighted in the workers' reports: I had RSI, I got tendinitis. I got bad, didn't know what it was, and I let it be, you get afraid too, let it be, pretend it's nothing, then it got worse to the point I was in no condition to work, it got really bad. I stayed on leave for six and a half months, doing physical therapy... I got back to work because I couldn't stand not working, you even get a little depressed, because it doesn't show. It's not something that everybody sees you have. I've suffered prejudice on the part of my own colleagues. They would say 'ah, she can go out, she can walk, she can travel, she only can't work' [...] everybody working there in that madness, everybody became a little resentful. I went back [...] stayed on leave for six and a half months and then went back to work. After three months working, I had to leave again, I went to work and my hand got swollen, my arm got pretty swollen, my hand got purple, I got there at ten and at midday I couldn't work anymore, because $I$ wasn't able to even pick up a pen to write. [...] I stayed another three and a half months on leave. (Interviewee 5)

This report brings important information that describes the experiences of becoming sick, being on leave and getting back to work that took place in the studied institution. The transformations that occurred in a great part of the bank tasks had important consequences for the health of workers, especially, work conditions conducive to the development of diseases such as WRMD and $\mathrm{RSI}^{(20)}$

Labor has certainly evolved toward increased productivity with the incorporation of technology strengthened by automation and specialization(21). This context forces bank employees to work in a nonergonomic fashion, dictated by an accelerated pace and under conditions frequently related to WRMD(21). The disturbing existence of occupational diseases among bank employees reveals how organizational changes do not improve work conditions ${ }^{(22)}$. Such a fact is reported in the interviewees' reports: Last year I took a four-month leave because of tendinitis in my arms, biceps, shoulder. I was a bank teller for 24 years. Everything was ok, I had no problem, thank God... of course, I think they would find a way to fire me if it wasn't for the labor union. Once you get this disease, there's no cure, it's something you'll have forever. I try to work, and 
the worse thing is that I'm not able to reduce my pace, I try to work slower, but I can't. So, sometimes I have pain and I know I won't be able to work to the end, but... (Interviewee 10)

[...] I was a bank teller in 2003. Pressure... would leave about 9 at night. I got sick, stayed hospitalized for 11 days with a very strong headache. I started to take medication because I couldn't sleep, tension, pain in my neck, headaches, I started to take Rivotril, Captopril, Miozan, muscle relaxants and antidepressants. I took these medications and treatment for three years. It was disturbing my private life, especially the antidepressants, which completely disturb you.... I stopped taking the medications, only then I can't anymore, I'm completely dependent on anxiolytic and antidepressants. I can't live without it. I took the treatment, went back to work and then in 2006 I got this problem in my back. I have cervical disc protrusion, three herniated lumbar discs, tendinitis in both shoulders... and carpal tunnel syndrome. I got sick twice in the bank since then, I felt my right side go numb, my mouth started to tingle... It was compromised; the herniated cervical disc pinches the nerve that corresponds to my right side. I went back to work in 2006 when I developed the herniated cervical disk, but then in 2007 my right side was compromised and I went on leave [...] (Interviewee 9).

One of the studies that is referenced for the health of bank employees in Brazil(22) observed that the physical pain of workers affected by RSI and WRMD is worsened by the loss of the ability to work, which leads to the emergence of mental suffering: I was diagnosed with Panic Disorder, stress, strong depression... but I'm not sure what I have... I just want to stay home in bed. I can't see a couch that I go lie on it. When I get to places I need half an hour to calm down. (Interviewee 2).

The sick leave also works as a social recognition of the disease(23). Going back to work after being on sick leave ${ }^{(24)}$ revealed that "the fear and shame that workers who may remain in the company experience is related to constantly living what one worker called 'the syndrome of the corner', that is, a life combines the experience of isolation with the feeling of uselessness, invisibility of tasks and corresponding results, of oneself as worker in the face of his peers"(24): There is no other function in the bank that I don't have to type, everything today in a bank is typed. So, it doesn't help changing departments, and also I don't want to be like many people in many banks, when they get this type of disease [RSI/WRMD], they maintain a certain stability and people leave the person aside. So I'd rather stay in my position and work slowly than be like a burden. (Interviewee 10).

The history of the studied institution gives continuity to the history of the Brazilian financial sector and its market trends, and consequently, presents the problems faced by workers that are a consequence of the new paths adopted. Data obtained in the interviews encourage reflection on issues reported in the literature and that, unfortunately, continue to happen in the bank environment.

\section{Final considerations}

The main contribution of this study consisted in exposing, from the perspective of workers, how working conditions, the constant organizational changes and changes in the work process are linked to the health of bank employees. From the perspective of capital, most studies consulted highlight that the changes that integrate the productive restructuring resulted in increased productivity and profit in the sector. On the other hand, from the labor point of view, a reduction in job positions, intensification of work, overload of tasks, increased control and pressure on workers were observed, which strongly reflected on the work conditions and health of workers in the field. The pioneering of automation and computer resources was quick to take its toll- the Brazilian financial sector rapidly became a pioneer in the report of RSI and WRMD cases, diseases closely related to intensification of work. Such a fact was also noted in the interviewees' reports.

The considerable reduction in job positions intensified the volume of work for those who remained, as well as for new employees. Increased pressure, expressed by the need to meet increasingly unattainable goals and the recurrent disrespect concerning the duration of work hours, aggravated the health of bank employees as verified in this study's reports.

For many of the young individuals working in banks, this professional activity is seen as a way to enter the job market, from which they try to "leverage" other career goals. These are the individuals who have presented growing indexes of occupational diseases in the sector. From a situation considered to be temporary, many become "marked" for their entire professional path.

Even though the new profile of bank employees includes being able to assume varied tasks, having flexible hours and greater responsibility, the profession has been impoverished. According to the interviewees, banking work is marked by an empty professional identity, loss of personal growth and being a source of suffering and discontentment, which can interfere in the health of this population.

The data obtained suggest that the introduction of new technologies and organizational innovations were 
indicated as being responsible for redefining positions, tasks, and ways of acting and thinking within banks, which especially led to professional devaluation. Issues related to health and illness are imbricated in this context of changes. It appears that through understanding of how work is organized and how it is explored, it is possible to establish relationships between health and work. Hence, it was essential in the search to understand the process in which bank employees become sick to go back to the productive restructuring process, highlighting the changes that were implemented in the organizational and work processes for this profession and their implications for health.

\section{References}

1. Filgueiras L. Reestruturação produtiva e emprego bancário. In: O Trabalho no séc. XXI: considerações para o futuro do trabalho. São Paulo: Anita Garibaldi; 2001. p. 279-99.

2. Santos MAF, Siqueira MVS, Mendes AM. Tentativas de suicídio de bancários no contexto das reestruturações produtivas. Rev Adm Contemp.2010;14(5):925-38.

3. Segnini LRP. Reestruturação nos bancos do Brasil: desemprego, subcontratação e intensificação do trabalho. Educ Soc. 1999;20(67):185-211.

4. Jinkings $N$. As formas contemporâneas da exploração do trabalho nos bancos. In: Antunes R, Silva MAM, organizadores. $O$ avesso do trabalho. São Paulo: Expressão Popular; 2004. p. 207-41.

5. Silva LS, Pinheiro TMM, Sakurai E. Reestruturação produtiva, impactos na saúde e sofrimento mental: o caso de um banco estatal em Minas Gerais, Brasil. Cad Saúde Pública. 2007;23(12):2949-58.

6. Gravina MER, Rocha LE. Lesões por esforços repetitivos em bancários: reflexões sobre o retorno ao trabalho. Cad Psicol Soc Trab. 2006;9(2):41-55.

7. David ML. A transformação dos processos de trabalho e a descaracterização da profissão de bancário. $4^{a}$ Semana de Ensino, Pesquisa e Extensão. Santa Catarina: UFSC; 2004.

8. Netz SR. As diversas formas de executar o trabalho bancário. $5^{\circ}$ Congreso Latinoamericano de Sociologia del Trabajo - Hacia una nueva civilización del trabajo. Montevidéu, Uruguai; 2007.

9. Grisci CLI. Tempos modernos, tempos mutantes: produção de subjetividade na reestruturação do trabalho bancário". Rev Psicol Soc. 2001;13(1):75-92.
10. Grün R. Taylorismo e fordismo no trabalho bancário: agentes e cenários. Rev Bras Ciênc Soc. [periódico na Internet]. 1986;1(2):13-27. [acesso 13 set 2008]. Disponível em: http://www.anpocs.org.br/portal/ publicacoes/rbcs_00_02/rbcs02_02.htm.

11. Batista E. A (des)qualificação do trabalho bancário na era neoliberal: um enfoque qualitativo sobre o Banco do Brasil. $6^{\circ}$ Seminário do Trabalho. Marília: UNESP; 2008.

12. Góes AOS, Souza MEA. A transformação da prática do bancário e a exigência de múltiplas competências. RAC-E. [periódico na Internet]. 2008;2(1):123-40. [acesso 13 set 2008]. Disponível em: http://www. anpad.org.br/periodicos/arq_pdf/a_689.pdf

13. Merlo ARC, Barbarini N. Reestruturação produtiva no setor bancário brasileiro e sofrimento dos caixas executivos: um estudo de caso. Rev Psicol Soc. 2002;14(1):103-22.

14. Guedes RC. Bradesco SA: uma cultura organizacional forte dentro do sistema bancário brasileiro 2001. [acesso 13 set 2008]. Disponível em: sites.uol.com.br/ ritacguedes/pub001.htm

15. Fleury MTL. Cultura Organizacional - os modismos, as pesquisas, as intervenções: uma discussão metodológica. Rev Admin. 1989;24(1):3-9.

16. Jinkings N. O Mister de Fazer Dinheiro. São Paulo: Boitempo; 1995. 136 p.

17. Maciel RH, Cavalcante R, Matos TGR, Rodrigues $S$. Auto relato de situações constrangedoras no trabalho e assédio moral nos bancários: uma fotografia. Rev Psicol Soc. $2007 ; 19(2): 117-28$.

18. Castelhano LM. O medo do desemprego e a(s) nova(s) organizações de trabalho. Rev Psicol Soc. 2005;17(1):17-28.

19. Sznelwar LI, Massetti M. Agressões ao corpo e/ou sofrimento psíquico? Um estudo construído a partir da experiência de trabalhadores com LER/DORT. Travailler. 2002;(8):153-76.

20. Murofuse NT, Marziale MHP. Mudanças no trabalho e na vida de bancários portadores de lesões por esforços repetitivos: LER. Rev. Latino-Am. Enfermagem. 2001;9(4):19-25.

21. Brandão AG, Horta BL, Tomasi E. Sintomas de distúrbios osteomusculares em bancários de Pelotas e região: prevalência e fatores associados. Rev Bras Epidemiol. 2005;8(3):295-305.

22. Ribeiro HP. A violência oculta do trabalho. Rio de Janeiro: Fiocruz; 1999. 
23. Carrijo DCM, Navarro VL. LER e Planos de Demissão Voluntária: trajetórias de dor e sofrimento entre bancários. Cad Psicol Soc Trab. 2009;12(2):157-71.

24. Borsoi ICF, Santos AOR, Acário SHA. Trabalhadores amedrontados, envergonhados e (in) válidos: violência e humilhação nas políticas de reabilitação por LER/DORT.

Rev Psicol Política. 2006;6(12):1-22. 